\title{
BRAF NP_004324.2:p.G469S
}

National Cancer Institute

\section{Source}

National Cancer Institute. BRAFNP 004324.2:p.G469S. NCI Thesaurus. Code C98323.

A change in the amino acid residue at position 469 in the serine/threonine protein kinase

B-raf protein where glycine has been replaced by serine. 